Rev. Téc. Ing. Univ. Zulia. Vol. 42, No. 2, 2019, 50-56

\title{
Determination of the physical properties of fermented and dried Venezuelan Trinitrio cocoa beans (Theobroma cacao L.)
}

\author{
Aleida J. Sandoval ${ }^{1} \mathbb{D}_{\text {,José }}$ A. Barreiro ${ }^{1^{*}}$ (D), Andrea De Sousa ${ }^{1}$ (D), Danny Valera ${ }^{1}$ and \\ Alejandro J. Müller ${ }^{2} \mathbb{D}$
}

\author{
${ }^{1}$ Dept. de Tecnología de Procesos Biológicos y Bioquímicos. \\ ${ }^{2}$ Dept. Ciencia de los Materiales. Universidad Simón Bolívar, Aptdo. 89000, Caracas 1080-A, Venezuela. Tel-Fax: \\ +58 2129063953 , *e-mail: asandova@usb.ve \\ https://doi.org/10.22209/rt.v42n2a01 \\ Recepción: 02/05/2018 | Aceptación: 16/10/2018| Publicación: 01/05/2019
}

\begin{abstract}
Some important physical properties of Venezuelan Trinitario cocoa beans (Theobroma cacao L.) were determined, such as average dimensions of beans (length, width and thickness), bean weight; weight of 1000-beans; sphericity; geometric diameter; geometry index; surface area; bean volume; bulk density; particle density; and porosity. The shape of the beans could be approximated to that of a scalene ellipsoid, characterized by three different orthogonal dimensions (length, width and thickness). This fact was confirmed by experimental results of bean volume with theoretical equations developed for that geometry. The filling and emptying angles of repose were determined, as well as the static friction coefficient on different surfaces (nitrile rubber, plywood, galvanized steel, carbon steel, glass and stainless steel).
\end{abstract}

Keywords: cocoa bean, water activity, physical properties

\section{Determinación de las Propiedades Físicas de Habas Fermentadas y Secas de Cacao Trinitario Venezolano (Theobroma cacao L.)}

Resumen

Se determinaron algunas propiedades físicas importantes de habas de cacao Trinitario venezolano (Theobroma cacao L.) fermentadas y secas, incluyendo sus dimensiones promedio (longitud, ancho y espesor), así como peso de un haba; peso de 1000 habas; esfericidad; diámetro geométrico; índice geométrico; área superficial; volumen de un haba; densidad aparente; densidad de partícula; y porosidad. La forma de las habas puede aproximarse a la de un elipsoide escaleno, caracterizado por tres dimensiones ortogonales (longitud, ancho y espesor). Esto fue confirmado por los resultados experimentales. Se determinaron los ángulos de reposo de llenado y vaciado, así como el coeficiente estático de fricción para diversas superficies (caucho de nitrilo, madera contra-enchapada, acero galvanizado, acero al carbono, vidrio y acero inoxidable).

Palabras clave: habas de cacao, actividad de agua, propiedades físicas. 


\section{Introduction}

International trading of Trinitario cocoa beans (a hybrid of Criollo and Forastero types), is an important commodity export for Venezuelan along with the Criollo type. These varieties are used as fine flavor beans to be mixed with other cocoa bean varieties in order to improve flavor and aroma of chocolate and other cocoa products. This product is usually well fermented; sun dried and packaged in new jute clean sacks. If well fermented and if it complies with the required Venezuelan quality standards [1], cocoa beans are classified as fine first quality ("Fino de Primera").

Physical properties of food products, including cocoa beans, are required for proper engineering design of processing, cleaning, grading, conveying, drying, and transportation equipment. Also, they are important for analyze the heat and mass transfer processes involved in processing and preservation. Few research works regarding the physical properties of cocoa beans have been found in the literature. Bart-Plange and Baryeh [2] determined different physical parameters for category B cocoa beans from Ghana (i.e., beans having less than 100 -beans in a $100 \mathrm{~g}$ sample). The authors studied a moisture range from 5.68 to $24 \%$ (wet basis), finding that the moisture content did not have any remarkable influence on dimension ratios L/T (length to thickness) and $\mathrm{W} / \mathrm{T}$ (width to thickness). The same phenomenon was found for sphericity and surface area. As expected, higher moisture resulted in an increase in the average individual weight, 1000-bean weight, particle density, porosity, angle of repose, coefficient of friction and a decreased effect in bulk density. Proximate analyses of whole cocoa beans have been reported by different authors [3-6] for both non-fermented and fermented whole cocoa beans from Venezuela. Afoakwa et al. [7] studied the change in composition of cocoa beans during pod pretreatment and fermentation. Pod pretreatment consisted on storing the pods at temperature of $25-28{ }^{\circ} \mathrm{C}$ and $85-100 \%$ relative humidity for periods from 3-10 days.

There is limited information in the scientific literature regarding the physical-chemical properties of cocoa beans and particularly of the Trinitario type, grown in Venezuela. The objective of this research work is to determine important physical properties of Venezuelan fermented and dried Trinitario cocoa beans.

\section{Experimental Section}

Raw material, sample preparation and
characterization

Fermented cocoa beans Trinitario type, were grown and harvested in 2014, at Cúpira (Pedro Gual municipality), Miranda state, Venezuela, and packed in new clean jute sacks. The cocoa beans were graded as well fermented fine first grade (Fino de Primera), by Cacao de Origen, Hacienda La Trinidad, Caracas, Venezuela, according to the Venezuelan standard for cocoa beans [1]. A composite sample of about $5 \mathrm{~kg}$ of cocoa beans was provided by the same.

The chemical characterization of the cocoa beans used in this research was carried out and reported in a previous work [8]. The values reported for the proximate analysis were $(\mathrm{g} / 100 \mathrm{~g} \pm$ standard deviation): Moisture $=6.51 \pm 0.05$; fat $=44.23 \pm 0.30$; protein = $12.65 \pm 0.22$; ash $=3.34 \pm 0.03$. The water activity measured $\left(25-27^{\circ} \mathrm{C}\right)$ averaged $0.617 \pm 0.010$.

The study of physical characteristics of cocoa beans was restricted to the practical moisture content range required for proper cocoa bean preservation after fermentation and drying (6-7\% wet basis). For all the experimental parameters determined, the statistical measures of central tendency and dispersion were calculated. The following measurements were done:

a) Average bean dimensions. A 100-bean sample was randomly selected from a divided 1000-bean sample, and the characteristic perpendicular dimensions of each bean measured using a vernier caliper, Scienceware ${ }^{\mathrm{TM}}$ type $6914( \pm 0.1 \mathrm{~mm})$ [2]. The characteristic dimensions (mm): length (L), width (W) and thickness (T) are shown in Figure 1.

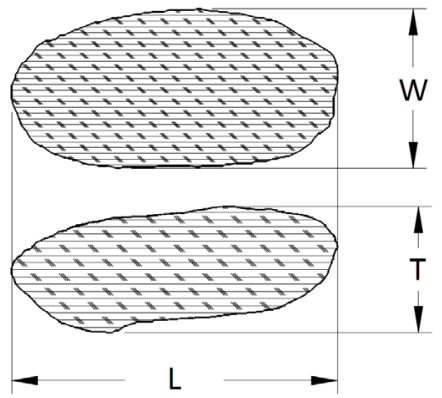

Figure 1. Dimensions of cocoa beans (L: length, W: width, T: thickness)

The following physical properties were calculated with the average bean dimensions (L, W, T), using the equations recommended by the references indicated:
b) Geometric diameter $\mathrm{D}_{\mathrm{g}},[9]: \mathrm{D}_{\mathrm{g}}=(\mathrm{L} \cdot \mathrm{W} \cdot \mathrm{T})^{1 / 3}$
c) Sphericity $\Phi[2,9,10]: \Phi=(\mathrm{L} \cdot \mathrm{W} \cdot \mathrm{T})^{1 / 3} / \mathrm{L}$
d) Geometry index [11]:
$\mathrm{G}^{\prime}=\frac{1}{4}+\frac{3}{8} \cdot\left(1 /(\mathrm{W} / \mathrm{T})^{2}+1 /(\mathrm{L} / \mathrm{T})^{2}\right)$ 
e) Bean surface area $\mathbf{S}\left(\mathrm{mm}^{2}\right)[12]$ :

$S \approx \pi\left[(1-1 / \sqrt{3})(\mathrm{ab}+\mathrm{ac}+\mathrm{bc})+(1+1 / \sqrt{3})\left(a^{2} b^{2}+a^{2} c^{2}+b^{2} c^{2}\right)^{1 / 2}\right]$

Where $\mathrm{a}, \mathrm{b}$ and $\mathrm{c}$ are the semi-dimensions of the scalene ellipsoid $\mathrm{l} / 2, \mathrm{w} / 2$ and $\mathrm{t} / 2$ respectively.

Bean surface area $\mathbf{S}\left(\mathrm{mm}^{2}\right)[13]: S=\left(\pi \mathrm{D}_{\mathrm{g}}\right)^{2}$

f) Individual bean weight and weight of 1000-beans. Average individual bean weight was estimated weighing five 100-bean samples selected at random using an Ohaus $^{\mathrm{TM}}$ analytical balance, model Adventurer $( \pm 0.0001$ g) and calculating in each case the average weight of one bean. Weight of 1000-beans was calculated weighing five 1000-bean samples selected at random in an electronic Mettler ${ }^{\mathrm{TM}}$ balance model PM16-N ( $\pm 0.1 \mathrm{~g}$ ).

g) Bulk density. Bulk density $\left(\rho_{\mathrm{b}}\right)$ was determined using a test weight method at room temperature $\left(21^{\circ} \mathrm{C}\right)$. The cocoa beans were filled by gravity, in a calibrated cylindrical container with known volume $(469.5 \mathrm{~mL})$, from a height of $5 \mathrm{~cm}$ above the edge of the container. The top was leveled with a ruler without compaction after taping a couple of times. The container was emptied and the beans weighed using an electronic Mettler ${ }^{\mathrm{TM}}$ balance model PM16-N ( $\pm 0.1 \mathrm{~g}$ ). Bulk density was calculated dividing the sample weight $\left(\mathrm{W}_{\text {beans }}\right)$ by the container volume $\left(\mathrm{V}_{\mathrm{cnt}}\right)$. The experiment was done by sextuplicate.

h) Volume and particle density. Cocoa bean volume (V) and density $\left(\rho_{\mathrm{p}}\right)$ were evaluated by triplicate, using the pycnometric method with toluene described elsewhere $[9,14]$. In each experiment, the sample consisted in three beans selected at random. Both, the sample (Ws) and the pycnometers (Wp) were weighed using an analytical balance (Ohaus ${ }^{\mathrm{TM}}$, Adventurer $\pm 0.0001 \mathrm{~g}$ ). The pycnometers had a certified volume of about $25 \mathrm{~mL}$. The experiments were done at constant temperature using a PolyScience ${ }^{\mathrm{TM}}$ thermostatic bath at $20^{\circ} \mathrm{C}\left( \pm 0.01^{\circ} \mathrm{C}\right)$. Toluene ACS reagent grade (>99.5\%), Fluka Chemie AG, was used. The following formula was used:

$\mathrm{V}_{\mathrm{s}}=\mathrm{W}_{\mathrm{s}} / \rho_{\mathrm{tol}}=\left[\left(\mathrm{W}_{\mathrm{ps}}-\mathrm{W}_{\mathrm{p}}\right)-\left(\mathrm{W}_{\mathrm{pts}}-\mathrm{W}_{\mathrm{pt}}\right)\right] / \rho_{\mathrm{tol}}$

Being: Vs: total volume displaced by sample $(\mathrm{mL})$, Ws: sample weight $(\mathrm{g}), \mathrm{Wp}$ : weight of the empty pycnometer (g), Wpt: weight of the pycnometer filled with toluene (g), Wps: weight of the empty pycnometer with sample (g), Wpts: weight of the pycnometer filled with sample and toluene $(\mathrm{g}), \rho_{\text {tol }\left(20^{\circ} \mathrm{C}\right)}$ toluene density at $20^{\circ} \mathrm{C}=0.8623 \mathrm{~g} / \mathrm{mL}$ [15]. The average volume of one bean $\mathrm{V}(\mathrm{mL})$ was the total sample volume displaced by sample (Vs) divided by three. The particle (bean) density $\left(\rho_{\mathrm{p}}\right)$ was calculated by dividing the weight of the sample of beans by the volume of toluene displaced by them with the following equation:

$$
\rho_{\mathrm{p}}=\left(\mathrm{W}_{\mathrm{s}}\right) / \mathrm{V}_{\mathrm{s}}=\left[\left(\mathrm{W}_{\mathrm{ps}}-\mathrm{W}_{\mathrm{p}}\right)\right] / \mathrm{V}
$$

In order to compare the experimental volume obtained with the volume of a scalene ellipsoid, the exact mathematical formula can be used $[12,16])$ :

$$
\mathrm{V}=(4 \pi / 3) \mathrm{a} \mathrm{b} \mathrm{c}
$$

In this case, the linear semi-dimensions of the beans measured before: $\mathrm{L} / 2, \mathrm{~W} / 2$ and $\mathrm{T} / 2$ were used for the calculation.

i) Porosity $(\varepsilon)$. It is the fraction of void space existing in a bulk bean volume entraining air and not occupied by the beans [17]. It can be calculated with the particle density $\left(\rho_{\mathrm{p}}\right)$ and the bulk density $\left(\rho_{\mathrm{b}}\right)$ using the equation (9) $[2,14])$ :

$$
\varepsilon=\left(\rho_{\mathrm{p}}-\rho_{\mathrm{b}}\right) / \rho_{\mathrm{p}}
$$

j) Angles of repose and static friction coefficient. The filling angle of repose $\left(\theta_{f}\right)$ was determined by quintuplicate using a hollow plastic cylinder open at both ends with a diameter of $14 \mathrm{~cm}$ and height of $50 \mathrm{~cm}$. The cylinder was centered over a raised flat glass circular support with a diameter of $20 \mathrm{~cm}$ and filled with cocoa beans. The cylinder was slowly lifted at a rate of about $2 \mathrm{~cm} / \mathrm{s}$ until the entire cylinder was discharged and the product accumulated over the glass support forming a cone. The heap height $(\mathrm{H})$ and diameter (D) of the cone were measured using a metric tape $( \pm 1 \mathrm{~mm})$. The angle of repose $\theta_{f}\left({ }^{\circ}\right)$ was calculated using the trigonometric formula:

$$
\theta_{\mathrm{f}}=\tan ^{-1}(2 \mathrm{H} / \mathrm{D})
$$

The emptying angle of repose $(\theta)$ was determined by quintuplicate using a method similar to that presented by Koocheki et al. [14]. A wooden box of approximately $20 \times 20 \times 20 \mathrm{~cm}$ open on top and with a removable side panel was placed over a flat surface and filled with cocoa beans. The side panel was rapidly lifted in order to allow the beans to flow forming a wedge of beans. The angle was calculated from measurements done with a metric tape $( \pm 1 \mathrm{~mm})$ of the height of the heap at two points and the horizontal length between them, applying the trigonometric equation:

$$
\theta_{\mathrm{e}}=\tan ^{-1}\left[\left(\mathrm{HO}_{\mathrm{a}}-\mathrm{HO}_{\mathrm{b}}\right) / \mathrm{Z}\right]
$$

Where $\theta_{\mathrm{e}}$ is the emptying angle of repose $\left(^{\circ}\right)$, $\mathrm{H} 0_{\mathrm{a}}, \mathrm{HO}_{\mathrm{b}}$ are the heap height at two points $(\mathrm{mm})$, and $\mathrm{Z}$ the horizontal distance between points $\mathrm{HO}_{\mathrm{a}}$ and $\mathrm{HO}_{\mathrm{b}}(\mathrm{mm})$

The static friction coefficient $\left(\mu_{s}\right)$ of the beans 
was determined by the method outlined by Kaliniewicz et al. [18]. For this purpose, flat friction plates of different materials were used (plywood, galvanized steel, stainless steel, carbon steel, glass and rubber). These are materials frequently used for transportation, storage and handling grains and seeds. The rugosity of each surface (Ra) was measured using a Mitutoyo Surftest-211 surface roughness tester. This device was previously calibrated (Ser. $310179 / 2.95 \mu \mathrm{m}$ ). All tests were conducted at a controlled temperature $\left(20 \pm 1^{\circ} \mathrm{C}\right)$. Ten measurements were done for each surface tested. The test plate had an adjustable angle of inclination graduated by means of a hydraulic piston. Five beans were randomly selected for each experiment. The orientation of the longitudinal axis of beans on the friction plate in relation with the direction of movement was set at different angles from $0,45,90$, and $135^{\circ}$ approximately. The experiments were done by quintuplicate for each surface. The inclination angle $(\alpha)$ at which bean motion started was calculated by trigonometry:

$$
\alpha=\sin ^{-1}\left[\left(\mathrm{H}_{2}-\mathrm{H}_{1}\right) / \mathrm{X}\right]
$$

Where, $\mathrm{H}_{2}$ and $\mathrm{H}_{1}$ are the height over the horizontal plane of the inclined friction plate at two points separated a distance $\mathrm{X}$ along the plate, measured with a metric tape $( \pm 1 \mathrm{~mm})$; and $\alpha$ is the inclination angle of the friction plate at which the bean started to move. In this case, a sliding movement was observed, in view of the flat shape of most of the beans that prevented rolling. The static friction coefficient $\left(\mu_{\mathrm{s}}\right)$ was calculated as the tangent of the inclination angle $(\alpha)$.
Statistical analyses. Measures of central tendency and dispersion and Student t-tests were calculated using Microsoft Excel ${ }^{\mathrm{TM}} 2016$.

\section{Results and Discussion}

The results obtained for the evaluation of some physical properties of cocoa beans are presented in Table 1.

The visual assessment of Trinitario cocoa beans revealed an oblong-prolate shape, with three perpendicular dimensions as presented in Figure 1: length (L), width (W) and thickness (T). The results obtained for these dimensions are presented in Table 1 . These values were significantly larger $(\mathrm{p} \leq 0.05)$ than those presented by Bart-Plange and Baryeh [2] for beans from Ghana (Category B) with a moisture content of $8.6 \%$ (wet basis); and similar to those presented by Alvarez et al. [5] for commercial Venezuelan cocoa beans with $5.17 \%$ moisture content. Average dimensionless ratios calculated from dimensions measured in this work were: $\mathrm{L} / \mathrm{T}=2.51 \pm$ 0.31 and $\mathrm{W} / \mathrm{T}=1.43 \pm 0.22$. These ratios were similar to those presented by García-Alamilla et al. [10] for Mexican fermented Criollo cacao with moisture content of around $8 \%$ (dry basis) of $\mathrm{L} / \mathrm{T}=2.63$ and $\mathrm{W} / \mathrm{T}=1.54$. According to the triangular diagram for particle shape description [20], the cocoa bean shape was classified as E-class (elongate), based on the dimensionless ratios obtained: $\mathrm{T} / \mathrm{L}=0.498$; $\mathrm{W} / \mathrm{L}=0.699 ;(\mathrm{L}-\mathrm{W}) /(\mathrm{L}-\mathrm{T})=0.725$.

Table 1. Results obtained for some of the physical properties studied of Venezuelan fermented cocoa beans variety Trinitario with $6.51 \%$ average moisture content (wet basis).

\begin{tabular}{ccccc}
\hline Physical property & Mean value & Range & $\begin{array}{c}\text { Standard } \\
\text { deviation }\end{array}$ & $\begin{array}{c}95 \% \text { confidence } \\
\text { interval }\end{array}$ \\
\hline Length $(\mathrm{mm})$ & 23.8 & $26.8-20.6$ & 1.8 & $23.5-24.2$ \\
Width $(\mathrm{mm})$ & 13.5 & $15.9-11.3$ & 1.3 & $13.4-13.8$ \\
Thickness $(\mathrm{mm})$ & 9.6 & $11.4-7.6$ & 1.0 & $9.4-9.8$ \\
Sphericity & 0.61 & $0.74-0.51$ & 0.04 & $0.60-0.62$ \\
Geometric diameter $(\mathrm{mm})$ & 15.9 & $16.1-13.7$ & 0.53 & $15.8-16.0$ \\
Geometry index & 0.51 & $0.66-0.38$ & 0.07 & $0.50-0.52$ \\
Average bean volume $(\mathrm{mL})$ & 1.72 & $1.77-1.63$ & 0.05 & $1.59-1.85$ \\
Surface area $\left.(\mathrm{mm})^{2}\right)$ & 742.4 & $932.3-587.0$ & 74.4 & $727.8-757.0$ \\
Bean weight $(\mathrm{g})$ & 1.44 & $1.46-1.41$ & 0.02 & $1.41-1.47$ \\
1000-bean weight $(\mathrm{g})$ & 1421.3 & $1422.8-1418.6$ & 1.66 & $1419.2-1423.4$ \\
Bulk density $(\mathrm{g} / \mathrm{mL})$ & 0.552 & $0.561-0.542$ & 0.008 & $0.544-0.560$ \\
Bean density $(\mathrm{g} / \mathrm{mL})$ & 0.971 & $0.994-0.937$ & 0.030 & $0.897-1.044$ \\
Porosity (void fraction) & 0.432 & $0.438-0.422$ & 0.009 & $0.410-0.454$ \\
\hline
\end{tabular}


The sphericity, geometric diameter and geometry index were calculated with the bean dimensions obtained for each cocoa bean measured. Mean values, range, standard deviation and 95\% confidence interval for these parameters are presented in Table 1 . The average sphericity value obtained compares satisfactorily with that reported by Bart-Plange and Baryeh [2] and with those reported for fermented Mexican Criollo cocoa beans by Garcia-Alamilla et al. [10]. The value agreed qualitatively with that of an elongated solid, as commented before.

The average bean volume determined experimentally using the pycnometric method was 1.72 $\mathrm{mL}$ (Table 1). A volume of $1.62 \pm 0.45 \mathrm{~mL}$ was obtained using the exact mathematical equation (8) to determine the volume of a scalene ellipsoid. The statistical analysis showed that there were no significant differences $(p>0.05)$ in bean volume between the pycnometric experimental value and the mean value obtained using the mathematically exact equation for scalene ellipsoids, evidencing that Trinitario cocoa beans studied in this work could be safely approximated to this geometry. In view of this, the surface area was calculated using Flammenkamp's equation (4) for scalene ellipsoids. A single bean average surface area of $742.4 \pm 74.4 \mathrm{~mm}^{2}$ was obtained, (Table 1). The surface area was also calculated with equation (5) presented by McCabe et al. [13]. A single bean average surface area of $794.1 \pm 50.0 \mathrm{~mm}^{2}$ was obtained, with a range of $825.5-586.2 \mathrm{~mm}^{2}$ and $95 \%$ confidence interval from 784.1 to $804.0 \mathrm{~mm}^{2}$. The t-test showed that there was a significant difference $(\mathrm{p} \leq 0.05)$ between the mean value predicted by Flammenkamp's equation (4) and the average surface area calculated using equation (5), indicating that equation (5) is not adequate to predict the bean volume.

Average weight obtained for a single cocoa bean was $1.44 \mathrm{~g} \pm 0.03 \mathrm{~g}$ (Table 1 ). Values reported in the literature (1.19 to $1.26 \mathrm{~g}$ ) [2, 5, 6] evidenced smaller beans than in the present investigation. The weight of 1000-beans showed an average of $1421.3 \mathrm{~g} \pm 1.2 \mathrm{~g}$; which was significantly higher $(\mathrm{p} \leq 0.05)$ than the value presented by Bart-Plange and Baryeh [2] of $1124 \mathrm{~g}$ for Class B cocoa beans from Ghana with $7.5 \%$ moisture in wet basis.

There were no significant differences $(\mathrm{p}>0.05)$ in the bulk density of cocoa beans $\left(\rho_{b}=0.552 \pm 0.008\right.$ $\mathrm{g} / \mathrm{mL}$, Table 1) and the value reported by Bart-Plange and Baryeh [2] $(0.560 \mathrm{~g} / \mathrm{mL})$. No significant difference $(p>0.05)$ was found between the average particle density $\left(\rho_{p}\right)$ determined by the pycnometric method in this work $(0.971 \pm 0.030 \mathrm{~g} / \mathrm{mL}$, Table 1$)$ and that reported by BartPlange and Baryeh [2] of $0.935 \mathrm{~g} / \mathrm{mL}$ for cocoa beans with $6.5 \%$ moisture (wet basis).

Porosity $\varepsilon$ (void fraction), calculated from average values of bulk and particle density, showed an average value of $0.432 \pm 0.009$ (Table 1 ). This value was significantly different $(\mathrm{p} \leq 0.05)$ from the value reported by BartPlange and Baryeh [2] for cocoa beans from Ghana with a moisture content of $8.6 \%$ (wet basis). However, there were no highly significant differences ( $p>0.01)$ with the value reported by Nganhou et al. [21] of 0.456 using drying data of a bed of cocoa beans.

The results obtained for the frictional properties studied in the different surfaces and their rugosity are shown in Table 2.

Table 2. Frictional properties of Venezuelan Trininario cocoa beans with 6.51\% average moisture content (wet basis) on six different surfaces. Surface rugosity $(\mathrm{Ra})(\mu \mathrm{m})$ is shown in cursive script in parenthesis

\begin{tabular}{ccccc}
\hline Frictional property & Mean value & Range & $\begin{array}{c}\text { Standard } \\
\text { deviation }\end{array}$ & $\begin{array}{c}95 \% \text { confidence } \\
\text { interval }\end{array}$ \\
\hline Angle of repose $\left(^{\circ}\right)$ & & & 1.8 & $18.1-21.0$ \\
Emptying angle of repose $\left({ }^{\circ}\right)$ & 21.8 & $24.3-19.8$ & 1.9 & $19.9-23.6$ \\
Static friction coefficient $(\mu \mathrm{s})$ on: & & & \\
Plywood $(6.63)$ & 0.53 & $0.61-0.44$ & 0.08 & $0.49-0.57$ \\
Steel-galvanized $(0.66)$ & 0.49 & $0.53-0.41$ & 0.04 & $0.47-0.51$ \\
Steel-carbon $(1.15)$ & 0.47 & $0.49-0.35$ & 0.09 & $0.42-9.52$ \\
Stainless steel-304 $(0.48)$ & 0.28 & $0.39-0.25$ & 0.06 & $0.24-0.32$ \\
Rubber-nitrile $(1.56)$ & 0.62 & $0.71-0.36$ & 0.11 & $0.55-0.69$ \\
Glass $(0.05)$ & 0.42 & $0.58-0.30$ & 0.11 & $0.36-0.48$ \\
\hline
\end{tabular}

The average filling angle of repose and the average emptying angle of repose presented in Table 2 were significantly different $(p \leq 0.05)$ than the values presented by Bart-Plange and Baryeh [2] of 23.74 and 25.5 , respectively. This was probably due to the smaller size of cocoa beans used by them that resulted in larger 
angles of repose. The emptying angle of repose was larger than the filling angle as in the present investigation.

The average static friction coefficients for several surfaces are shown in Table 2. The static coefficient of friction strongly depends on the normal load, material properties, local interfacial strength and roughness parameters [22]. The variability found regarding the static friction coefficient when compared with the test surface rugosity could originate in the differences in cocoa beans weight, dimensions, bean surface irregularities, roughness and angles at which they were placed on the test surface. All those factors are known to affect the friction coefficient [18]. In the case of plywood, the rugosity and the static friction coefficient were determined in a direction perpendicular to the wood grain. There were no significant differences $(p>0.05)$ between the values of the static friction coefficient obtained for plywood and galvanized steel in this work and those presented by Bart-Plange and Baryeh [2] (0.54 and 0.46, respectively). As observed in Table 2, the static coefficient of friction was highest for nitrile rubber, decreasing for plywood, galvanized steel, carbon steel, glass and stainless steel. A similar behavior was found by Gupta and Kumar [23] for sunflower seed and kernels with rubber presenting the highest coefficient followed by plywood, mild steel, galvanized iron, aluminum and stainless steel.

\section{Conclusions}

Important physical properties of well fermented and dried Venezuelan Trinitario cocoa beans with $6.51 \%$ (wet basis) moisture content were obtained in this work, such as: bean dimensions; bean weight; weight of 1000-beans; sphericity; geometric diameter; geometry index; surface area; bean volume; bulk density; particle density; and porosity (void fraction). The shape of Trinitario cocoa beans studied can be approximated to a scalene ellipsoid, characterized by three different orthogonal dimensions (length, width and thickness). This fact could be established by taking into consideration that the bean volume obtained experimentally did not present a statistically significant difference $(\mathrm{p} \leq 0.05)$ with the volume for a scalene ellipsoid of the same dimensions calculated using the mathematically exact equation for solids of this geometry. The filling and emptying angles of repose were determined, as well as the static friction coefficient on different surfaces. This information is of engineering interest in the design of equipment for processing, handling and storing this product.

\section{References}

[1] Norma Venezolana Covenin 50:1995. Granos de cacao (2da revisión). Ministerio de Fomento.
Caracas, Venezuela

[2] Bart-Plange, A. and Baryeh, E.A.: "The physical properties of category B cocoa beans". J. Food Eng., Vol. 60, No. 3 (2003) 219-227.

[3] Sandoval, A. J. and Barreiro. J. A.: "Water sorption isotherms of non-fermented cocoa beans (Theobroma cacao)". J. Food Eng., Vol. 51, No. 2 (2002) 119-123.

[4] Sandoval, A. J., Barreiro, J. A., Tovar, X. and Angueira, M.: "Sorption characteristics of fermented cocoa powder (Theobroma cacao)". Rev. Téc. Ing. Univ. Zulia, Vol. 25, No. 1 (2002) 49-55.

[5] Alvarez, C., Pérez, E. and Lares, M.C.: "Physical and chemical characterization of fermented, dried and toasted cocoa almonds grown in Cuyagua, Aragua state". Agr. Trop., Vol 57, No. 4 (2007) 249-256.

[6] Lares Amaíz, M. C., Gutierrez, R., Perez, E. and Alvarez, C.: "Effect of roasting process on physical and physicochemical properties, proximate composition and fatty acid profile of the cocoa bean from Miranda state, Venezuela". Rev. Cient. UDO Agríc., Vol. 12, No. 2 (2012) 439-446.

[7] Afoakwa, E.O., Kongor, J. E., Takrama, J. and Budu, A. S.: "Changes in nib acidification and biochemical composition during fermentation of pulp preconditioned cocoa (Theobroma cacao) beans". Int. Food Res. J., Vol. 20, No. 4 (2013) 1843-1853.

[8] Sandoval, A.J., Barreiro, J.A., De Sousa A., Valera D., López, J.V., \& Müller, A.J. (2018). Composition and thermogravimetric characterization of Venezuelan fermented Trinitario whole and peeled cocoa beans (Theobroma cacao) and shells. Submitted for publication to Revista Técnica de la Facultad de Ingeniería de la Universidad del Zulia.

[9] Mohsenin, N. N.: "Physical Properties of Plant and Animal Materials: Structure, Physical Characteristics and Mechanical Properties". $2^{\text {nd }}$ ed. Gordon and Breach Science Publishers, New York, 1986.

[10] García-Alamilla, P., González-Lauck, V.W., De La CruzLázaro, E., Lagunes-Gálvez, L.M., and García-Alamilla, R.: "Description and physical properties of Mexican criollo cacao during post-harvest processing". Rev. Iber. Tec. Postcosecha, Vol. 13, No. 1 (2012) 58-65.

[11] Smith, R.E., Nelson, G. L. and Henruckson R. L.: "Analysis of transient heat transfer from anomalous 
shapes". Trans. ASAE, Vol. 10, No. 2 (1967): 236-245.

[12] Michon, G. P.: Final answers to scientific questions. Spheroids and scalene ellipsoids. Approximate surface area of a scalene ellipsoid. 2001. Retrieved on November 23, 2015 from Numericana.com. Website: www.numericana.com/answer/ellipsoid. htm\#ellipsoid

[13] McCabe, W. L., Smith, J. C. and Harriott, P.: "Unit Operations of Chemical Engineering". $5^{\text {th }}$ edition. McGraw Hill Inc, New York, 1986.

[14] Koocheki, A., Razavi, S.M.A., Milani, E., Moghadam, T.M., Abedini, M., Alamatiyan, S. and Izadkhah, S.: "Physical properties of watermelon seed as a function of moisture content and variety". Int. Agrophy., Vol. 21, No. 4 (2007) 349-359.

[15] Haynes, W.M.: "CRC Handbook of Chemistry and Physics”. 95th ed. CRC Press LLC. Boca Raton, 2015.

[16] Zwillinger, D.: “CRC Standard Mathematical Tables and Formulae". 31st edition. Chapman and Hall CRC, Boca Raton, 2003.

[17] Thompson, R. A. and Isaac, G. W.: "Porosity determination of grains and seeds with air comparison pycnometer". Trans. ASAE, Vol. 10, No. 5 (1967) 693-696.
[18] Kaliniewicz, Z., Markowski, P., Anders, A. and Jadwisieńczak, K.: "Frictional properties of selected seeds”. Tech. Sci., Vol. 18, No. 2 (2015) 85-101.

[19] Visvanathan, R., Palanisamy, P.T., Gothandapani, P.T. and Sreenarayanan, V.V.: "Physical properties of neem nut”. J. Agric. Eng. Res., Vol. 63, No. 1 (1996) 19-25.

[20] Graham, D. J. and Midgley, N. G.: "Graphical representation of particle shape using triangular diagrams. An Excel spreadsheet method". Earth Surf. Proc. Landform., Vol. 25, No. 13 (2000) 1473-1477.

[21] Nganhou, J., Lecomte, D. and Dumargue, P.: Heat and mass transfer through a thick bed of cocoa beans under stationary and transient inlet conditions. In Mujumdar, A.S. (Ed.). Drying '92: Proceedings of the 8th International Drying Symposium IDS '92, pp. 1514-1523. Montreal Quebec, Canada, 1992.

[22] Patil, D. B. and Tribol Lett, E. M.: "Effects of interfacial strength and roughness on the static friction coefficient". Trib. Lett., Vol. 569, No. 2 (2014) 355374.

[23] Gupta, R. K. and Kumar, S.: "Friction coefficients of sunflower seed and kernel on various structural surfaces". J. Agric. Eng. Res., Vol. 71, No. 2 (1998) 175-180. 


\section{REVISTA TECNICA}

DE LA FACULTAD DE INGENIERIA

UNIVERSIDAD DEL ZULIA

Vol. 42. N², Mayo -Agosto 2019, pp. 47 - 97

Esta revista fue editada en formato digital y publicada

en Abril de 2019, por el Fondo Editorial Serbiluz, Universidad del Zulia. Maracaibo-Venezuela

www.luz.edu.ve

www.serbi.luz.edu.ve

produccioncientifica.luz.edu.ve 